\title{
Improvement of Plastic Waste Processing In The Plastic Waste Processing Industry at Tanjungsari District Sumedang
}

\author{
AHMAD MUNANDAR ${ }^{1}$, KETUT ABIMANYU2 ${ }^{2}$ NURWATHI ${ }^{3}$, UDIN \\ KOMARUDIN $^{4}$, LENI HERDIANI ${ }^{5}$, R. ISMET RUHIMAT ${ }^{6}$ \\ ${ }^{1,3}$ Teknik Industri, Universitas Sangga Buana, ${ }^{2}$ Teknik Elektro, Universitas Sangga Buana \\ ${ }^{4}$ Teknik Mesin, Universitas Widyatama, 5,6 Teknik Industri, Universitas Langlangbuana \\ Email: ahmadmunandar@usbypkp.ac.id
}

Received 03 June 2020 | Revised 14 June 2020 | Accepted 24 June 2020

\begin{abstract}
The waste problem is a very complex discussion. Every day thousands of tons of waste are produced by industry and households. The most complicated problem of handling waste today is plastic. Until now, Indonesia is the number two plastic waste-producing country in the world, amounting to 187.2 million tons/year (2015). This problem needs to be solved scientifically, given the pollution generated by plastic waste is getting worse. One of the efforts made is to recycle plastic waste, such as the people of Cinanjung Village, Kutawaringin Village, and Hegarmanah Village, Tanjungsari District, Sumedang Regency. The problems that arise are (1) the process of making "butek" (plastic seeds) is still very traditional which endangers the safety of the craftsman and the surrounding environment, (2) the process of making plastic seeds requires a long time, (3) the production management system is managed simply. The solution offered is designing and making Plastic Lubricating Machines as well as management and technical training in the use of lubricating machines. From the use of the lubricating machine it can be concluded that; (1) the production process is efficient and effective, (2) occupational health and safety are concerned, (3) the quality of the product is better, (4) production management is organized and recorded.
\end{abstract}

Keywords: lubricating machines, plastic seeds, waste

\section{INTRODUCTION}

Discussing the waste problem is very complex. Every day thousands of tons of waste are produced by industry and households. Waste management must be integrated with all levels of the structure from the central government to the smallest environment, the family.

The most complicated problem of handling garbage today is plastic waste. Until now, Indonesia is the number two plastic waste-producing country in the world, amounting to 187.2 million tons, while China is 262 million tons (Jenna Jambeck, 2015). This problem 
needs to be solved scientifically, given the pollution generated by plastic waste is getting worse.

One of the efforts made is by recycling plastic waste. This recycling needs to be done so that in addition to reducing plastic waste, it can also be a source of income for the community. One of the waste recycling efforts carried out is to produce additional products that are sourced from plastic. This was done by the people of Cinanjung Village, Kutawaringin Village, and Hegarmanah Village, Tanjungsari District, Sumedang Regency. The community of these three villages processes plastic waste into various types of products, such as yarn waste, children's toys, household appliances, and others.

However, problems arise from the plastic waste processing industry, namely the processing of plastic waste which is carried out manually and traditionally. This is in addition to endangering lives, air pollution is also an inefficient production process. The production process is carried out by burning plastics directly on the floor and then crushed by chopping them into plastic seeds.

From the problems mentioned above, this paper tries to provide solutions for the community while solving the problem of waste (plastic crackle), namely by designing and making plastic lubricating machines.

With this machine, it is hoped that the community can overcome the problems of safety, pollution, and improvement in the quality of plastic seed products plastic seeds. Furthermore, the plastic seed can be sold directly to the market (the market is still open) or as raw material for injection molding machines into various types of products, such as yarn spun, children's toys, household appliances, and others. In addition to the design and manufacture of the lubricating machine, training is also carried out on the use of the lubricating machine and knowledge of waste, especially plastic waste.

\section{METHOD}

The main problems of this research are the process of making plastic seeds is still very traditional so that it endangers the safety of the craftsman and the environment, the process of making plastic seeds requires a long time, the production management system is managed simply.

Methods of community service are carried out with the following stages: research stages, design stages, making stages, training stages, post training stages.

\section{RESULTS AND DISCUSSION}

\subsection{Research Stage}

The study focused on reel yarn kite craftsman. Where almost all of the villager's income depends on this activity.

In producing this yarn reel, raw materials of plastic seeds are needed in quite large quantities. Before the increase in fuel, plastic seeds suppliers were quite numerous and the prices were quite affordable (around Rp. 2,500/kg), but since the increase in fuel, plastic seeds suppliers were rare and almost non-existent, even if there were prices that were almost $2 x$ fold (around Rp. 4,500/kg). This condition caused many yarn reel craftsmen to go bankrupt, which in turn increased the unemployment. 
While in the field, the process of making yarn waste from raw materials to finished goods is described as Figure 1 below.

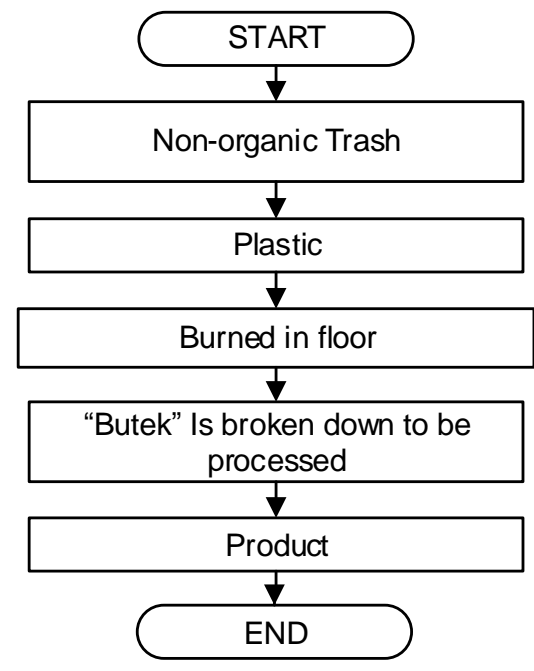

Figure 1 Workflow diagram of raw material process

\subsection{Design Stage}

The design of machines that can process from plastic waste into plastic pellets/plastic seeds, based on several criteria:

a. Machines/tools must be simple (appropriate)

b. Machines/tools must be mobility

c. Able to be operated by the community.

In the design process, given the financial conditions and time targets that have been determined, it is generally agreed to design and make plastic lubricating machines. The principle of this machine must be able to process plastic raw materials (plastic bags) into liquid plastic.



Figure 2: Platic Lubricating Machine Design

Following are the work principles :

a. The Diesel engine (high speed) drives the gearbox to produce low and strong rotation, which in turn drives the Screw Axle.

b. The stove (kerosene fuel) heats the screw tube so that when the plastic enters the screw tube, the plastic melts. 
Using plastic raw materials, crackle bags, sacks, etc., are put into the inlet container, and then pushed by the screw while heated by a stove, so that the plastic comes out in a melted condition in the form of noodles through the discharge hole.

\subsection{Making Stage}

The process of making lubricating and shredder machines is done on campus, using existing equipment assisted by lecturers and students. In the process of making a Pelumer Machine, the material and process needs are obtained. Material Requirement:

- Diesel motor $=1$ unit

- Gear Box (Reduction) = 1 unit

- Coupling (connecting) = 1 unit

- Bearing $=2$ pcs

- Pully = 2 pcs

- Screw Shaft $L=1.5 \mathrm{~m}$

- Screw Tube $=\varnothing=100 \mathrm{~mm}$

- Bearing housing $=\varnothing=120 \mathrm{~mm}$

- Steel Plate $=\mathrm{t}=1 \mathrm{~mm}$

- U and L profile steel, for frames

- Stove $=4$ pcs

- Cooker tube = 1 piece

- Steel Plate, for Screw = $\mathrm{t}=10 \mathrm{~mm}$

- Bolts and nuts

- Paint

Process Requirement:

- Turning Process, lathe

- Cutting processes, electric saws, machine cut plates

- Welding Process, Electric Welding, Acetylene Welding

- Formation Process, folding machine

- Discharge Process, Drilling machines

- Tools, hammers, files, compressors, emery, saws, taps, screwdrivers, keys, etc. Figure 3 shows the lubricating plastic machine.

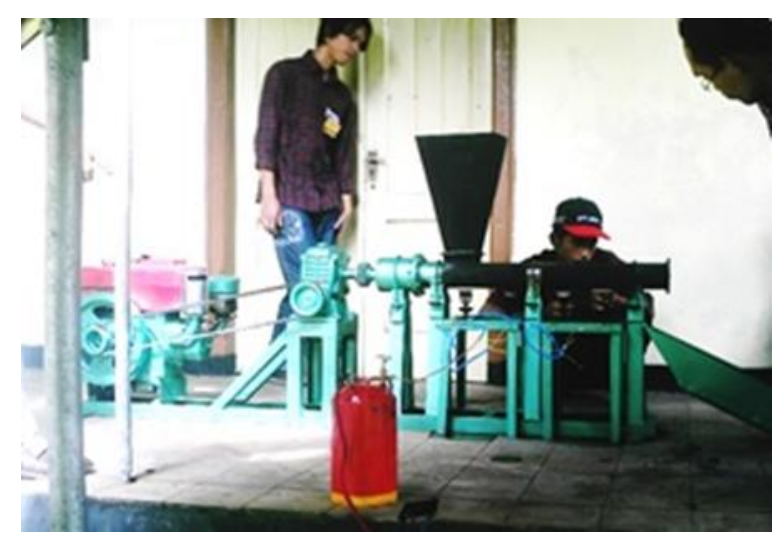

Figure 3. Lubricating Plasctic Machine

\subsection{Training Stage}

The training is carried out after the machine is finished and has been tested. This is to ensure that when the practice goes directly to the trainees.

a. Training Time

Starting from February 24 through February 27, 2015 
Improvement of Plastic Waste Processing In The Plastic Waste Processing Industry at Tanjungsari

b. Training Participants

The number of trainees is 30 participants with details; 10 people from Cinajung Village, 10 people from Kutamandiri Village, and 10 people from Hegarmanah Village.

c. Training Materials

1) Self-development, Basic management, and Entrepreneurship

2) Introduction to Technology

3) Plastic and Health Knowledge

4) Occupational Health and Safety

5) Lubricating and Shredder machine theory

d. Training Method

The method used is adult training, andragogy. Besides being given training material, participants were also invited to play an active role in solving a case that occurred in the field. So it happens interactively between participants and instructors.

e. Training Instructor

The instructors are consisting of Dadang Supriatna, MT (Chemical Analyst), Udin Komarudin, Ir. (Mechanical construction engineering), Ahmad Munandar, Ir. (Production management), Dedi Adiyono, MT. (Production techniques) and Nurwathi (Occupational Health and Safety).

f. Training Evaluation

Training evaluation is conducted to find out the results of the training, where each participant is given several questions. An evaluation is also carried out for the implementation of the training process, where the trainees conduct an assessment of the training.

Figure 4 shows the picture of the whole participants.

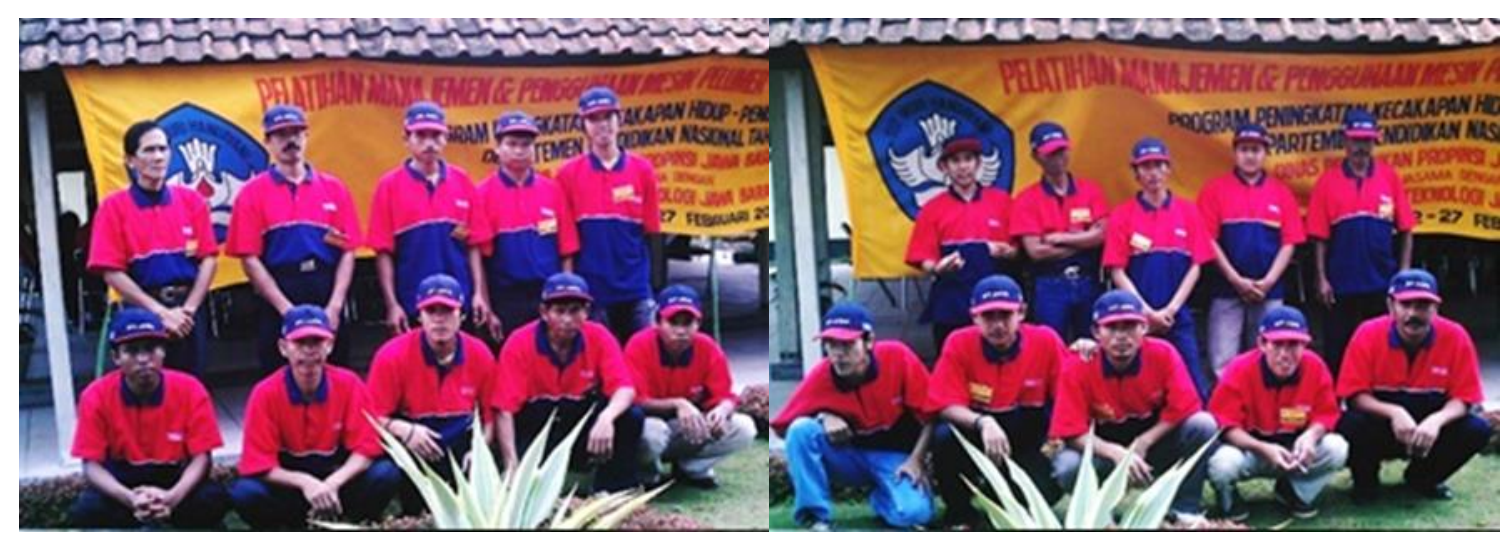

Figure 4. Training Participants

\subsection{Post Training Stages}

a. Business Unit Group

Post-training is done by forming an independent business unit in each group. Furthermore, during the 1 month after the training, assistance was provided in the form of visits to each business group. This is done to form an independent business unit that can develop themselves with the assistance that has been given.

b. Working Capital

Each group is entitled to post-training capital assistance in the form of a plastic puffing machine, 1 unit 
Improvement of Plastic Waste Processing In The Plastic Waste Processing Industry at Tanjungsari District Sumedang

C. Accompaniment

Assistance is carried out in the form of counseling to each group by visiting the group's place directly. Visits are made 3 times during the month.

Tabel.1 Visiting Time Activities

\begin{tabular}{|c|c|}
\hline Visit Time & Activities \\
\hline $1^{\text {st }}$ & Counseling care and use of lubricating machines \\
\hline $2^{\text {nd }}$ & Counseling for credit applications \\
\hline $3^{\text {rd }}$ & Counseling on management and quality of plastic seeds \\
& products \\
\hline
\end{tabular}

Figure 5 shows the result of lubricating plastic machine.
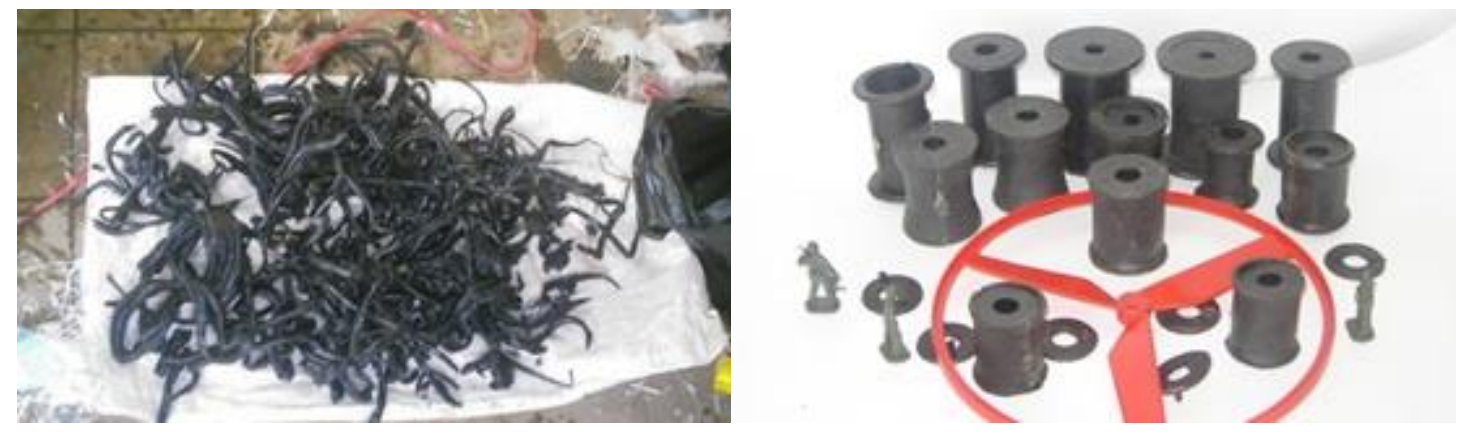

Figure 5. Butek and Plastic Product Result

\section{CONCLUSIONS}

The Community Service Program is very useful and helps the local community, especially in the process of processing plastic waste that prioritizes the efficiency and effectiveness of production, occupational health and safety, product perfection and production management are organized and recorded. Besides that, it can handle unemployment, the scarcity of plastic raw materials (pellets), and the problem of plastic waste.

\section{LIST OF REFERENCES}

Cross, N. (1994). Engineering Design Methods: Strategies for Product Design. John Wiley \& Sons. New York.

Hunger, J.D., Wheelen, Thomas, L. (2012). Manajemen Strategis. Andi, Yogyakarta.

Miller. (1990). Environmental Science: Sustaining The Earth. Wadsworth.

Parker, S. R. (1990). Sosiologi Industri. Rineka Cipta. Jakarta.

Rangkuti, F. (2006). Business Plan: Teknik Membuat Perencanaan Bisnis dan Analisis Kasus. Gramedia Pustaka Utama. Jakarta.

Takeshi, G.S, Hartanto, N.S. (1986). Menggambar Mesin Menurut Standar ISO. Cetakan ketiga. Pradnya Pramita. Jakarta. 
Improvement of Platic Waste Processing In the Plastic Waste Processing Industry at Tanjungsari District Sumedang

Ulrich, K. T., Eppinger, S.D. (1995). Product Design and Development. Mc Graw Hill.

Urban, G.L., Hauser, J. H. (1993). Design and Marketing of New Product. Prentice Hall, New Jersey. 